\title{
DE HABSBURGOS A BORBONES. LEGISTAS Y CANONISTAS EN LA REAL UNIVERSIDAD DE MÉXICO
}

\author{
Carlos Tormo Camallonga \\ Universitat de València
}

PLANTEAMIENTO DE LA CUESTIÓN*

T as matrículas de Leyes y Cánones de la Universidad de Mé_uxico en el siglo XviII han sido estudiadas magistralmente por Mariano Peset y Rodolfo Aguirre. En sus trabajos y en tantos otros publicados por diversos investigadores, especialmente en el seno del Instituto de Investigaciones sobre la Universidad y la Educación de la Universidad Nacional Autónoma de México, ha quedado de sobra acreditado que nos encontramos ante una universidad que, en cuanto al número de escolares y grados en sus facultades mayores, tenía una composición mayoritariamente canonista, además de teologal; una universidad, por lo tanto, esencialmente clerical. A larga distancia, y para Derecho,

Fecha de recepción: 4 de octubre de 2019

Fecha de aceptación: 20 de enero de 2020

* Agradezco el apoyo prestado para la realización de este trabajo por el Proyecto de Investigación PAPIIT, IN-402218, de la Universidad Nacional Autónoma de México. 
quedaban los estudiantes y grados en Leyes. ${ }^{1}$ Todo ello está en plena consonancia con la realidad dimanante de un Nuevo Mundo para el que el monarca había confiado a la Iglesia no solo su misión evangelizadora, sino también, y en gran parte, las funciones de gobierno y administración. ${ }^{2}$

Así pues, y desde la reconocida preeminencia de los estudios jurídicos de Cánones sobre los muy secundarios de Leyes, nuestro trabajo se centrará en matizar esta conclusión, generalmente aceptada como absoluta e inequívoca. ${ }^{3}$ Lo haremos, eso sí, en relación con un intervalo de tiempo muy concreto: el tránsito de la monarquía de los Austrias a la de los Borbones. Más exactamente tendríamos que hablar del tránsito de los siglos Xvir a xVIII, en la medida en que -y vaya como conclusión anticipadano parece que el cambio dinástico fuera el causante determinante de esta particular y transitoria preeminencia legista. Sin duda,

1 Peset, Mancebo y Peset, "La matrícula universitaria de México durante el siglo xviII". Aguirre Salvador, El mérito y la estrategia, pp. 30 y 78. En cuanto a textos y catedráticos puede verse MARTíNEz LóPEZ (coord.), 450 años de la Facultad de Derecho o Menegus Bornemann, "Tradición y reforma en la Facultad de Leyes", pp. 109-128, y "Las carreras de los graduados en Leyes y Cánones”, pp. 81-91.

2 Aguirre Salvador, "La carrera de los graduados fuera de la universidad", pp. 63-69, y TANCK de Estrada, “Tensión en la Torre de Marfil”, pp. 27-99.

3 No podemos caer en el error, sin embargo, de contraponer la situación novohispana con la de la Península, y creer que las universidades europeas primaban de manera irrefutable los estudios de Leyes. Para el siglo xviII la realidad será bastante más compleja. Así, en Alcalá de Henares no se dispuso de estudios legistas hasta los años ochenta, en que inmediatamente se impondrán a Cánones. Mientras, en Valladolid y Salamanca el predominio de Cánones será muy destacado a principios del siglo, y seguirá siendo evidente, aunque ya menos, a mediados del mismo, para verse superado por Leyes, aunque sin excesos, a partir de los años sesenta. En la de Valencia, por poner otro ejemplo, con una estructura académica menos clerical y más orientada hacia las profesiones, los estudios de Leyes predominarán en todo momento. En cualquier caso, sí es cierto que en la Península el avance de Leyes a lo largo del siglo xviII será imparable y generalizado, al contrario precisamente que en México. Véanse referencias de la nota núm. 1. 
deberemos tener en cuenta otros factores. Es decir, que no sabemos hasta qué punto la diferente concepción que ambas dinastías pudieron tener sobre sus dominios ultramarinos, si es que era diferente dicha consideración, repercutiría en la Universidad y, en concreto, en los estudios de Derecho. En este sentido, no parece que la contienda sucesoria tuviera grandes repercusiones en Indias más allá de las estrictamente económicas; de hecho, la documentación de la época sobre desavenencias al respecto en territorio americano es mínima. ${ }^{4}$

Lo que nos interesa destacar en estas páginas, en definitiva, es la particularidad de los últimos años del siglo xvir y primeros del xviII, dentro de esa pauta tradicional y ciertamente hegemónica a lo largo de toda la vida de la Universidad virreinal de Nueva España, como era la de la absoluta primacía de los estudios jurídicos de Cánones sobre los de Leyes. Esta singularidad legista lo será tanto por lo que respecta al considerable aumento comparativo de estudiantes durante el reinado del último Habsburgo, como al igualmente notable viraje en sentido contrario que tiene lugar con el primer Borbón, para que las cosas volviesen a su estado tradicional de preeminencia canonista. La historiografía ha considerado que, coincidiendo o con motivo de la transición dinástica, se impone desde la metrópoli una política restrictiva para las aspiraciones profesionales de los novohispanos en las altas instituciones radicadas en el propio territorio, tal y como igualmente sucedió, o se reforzó, a partir del reinado de Carlos III. Sin embargo, aquí veremos que no resulta tan sencillo entrelazar diversas y dispares referencias al respecto, con los supuestos efectos ocasionados sobre los estudios jurídicos. ${ }^{5}$

\footnotetext{
${ }^{4}$ Batista González, La estrategia española en América, pp. 21 y ss. Escamilla González, "La nueva alianza”, pp. 41-66. Navarro García, "La participación de México”, pp. 279-292.

${ }^{5}$ Hablamos, fundamentalmente, de la limitación de nombramientos para las plazas de las audiencias o de los cabildos eclesiásticos más importantes. TANCK de Estrada, “Tensión en la Torre de Marfil”, pp. 27-100.
} 
El origen de este trabajo parte del análisis comparativo que se puede realizar de este periodo en relación con cualquier otro del virreinato. Por cuestiones pragmáticas donde las haya o, lo que es lo mismo, por limitaciones documentales, nuestro estudio tomará como punto de referencia anterior los datos y cifras de principios del siglo xvII y, como punto de referencia posterior, los datos y cifras de finales del siglo XviII y principios del siguiente. Valga decir que de este último periodo es del que más estudios disponemos respecto a muchos de los temas que aquí nos interesan, y creemos que sus observaciones las podremos considerar, en líneas generales, como perfectamente extrapolables al transcurrir de la Universidad de México en cualquier época del virreinato. ${ }^{6}$ Contrariamente, nuestra labor se complica cuando tropezamos con la escasa atención que la historiografía jurídica y público-institucional ha prestado tradicionalmente a las primeras décadas del siglo XviII. Es más, consideramos que sus observaciones, en muchas ocasiones, resultan simplistas por genéricas. En los últimos años, sin embargo y afortunadamente, están apareciendo interesantes estudios sobre este periodo.

Aunque la limitación de datos documentales archivísticos nos obligará a entreverar teorías e hipótesis, que requerirán en el futuro de una mayor definición y perfeccionamiento, esperamos que valgan estas páginas como inicio de algo que en su momento pueda ser más extenso y completo.

\footnotetext{
${ }^{6}$ Por las mismas limitaciones materiales o archivísticas, en algunos análisis nos hemos visto en la obligación de tomar como referencia diferentes parámetros para cada momento. En unas ocasiones nos fijaremos mayormente en los cursos ganados en cada facultad, mientras que en otras lo haremos en el inicio de los estudios, o sea, en las matrículas de primero. No obstante, no son parámetros tan distantes en su significación, pues la matrícula, aunque sea un dato más parcial, no deja de ser una referencia determinante de los cursos después ganados.
} 


\section{LA PRIMACÍA DE CÁNONES FRENTE A LEYES}

La trascendencia que desde el momento de la conquista tuvieron los estudios de Derecho en la Universidad de México se explica, fundamentalmente, por la necesidad de que a las Indias alcanzara el organigrama funcional de la administración castellana. Nos encontramos con un aparato burocrático que, en los inicios de la Edad Moderna, estaba inmerso en una notable transformación en pro de la satisfacción de unas nuevas necesidades reales, en un contexto europeo político, social y religioso sustancialmente diferente al que lo había sido hasta entonces. Para las extensas tierras recientemente descubiertas, y que la monarquía hispánica sumaba a sus señoríos, se irá aprobando una legislación que, en cierta medida y al menos en un principio, concedería un tratamiento preferente a los españoles nacidos en Indias, lo que se concretaría, entre otras cosas, en una cierta prioridad para el acceso a los nuevos oficios, cargos, dignidades y beneficios que se estaban implantando, y que iban a dominar el Nuevo Mundo. En este sentido tendríamos que hablar, destacadamente, de la administración local. Era una de las principales y lógicas reivindicaciones de los conquistadores y colonos, así como de sus descendientes. ${ }^{7}$

Los primeros españoles asentados en el nuevo continente, pensando en la carrera literaria de que debían disponer los que deberían ocupar los nuevos mandos dirigentes, judiciales y administrativos en general, mostrarán una lógica preferencia, además de por los estudios de Teología, por los de Derecho. En ese último caso preferentemente por los de Cánones, dado que contaban con el beneficio de habilitar, además de para la carrera eclesiástica, tan importante aquí, para el ejercicio profesional civil, y viceversa. Además, las prohibiciones y limitaciones

\footnotetext{
7 Escandón Bolaños, “Apuntamientos”, pp. 93-123. Tormo Camallonga, "El régimen municipal en la Corona de Aragón”.
} 
impuestas en toda la monarquía a los clérigos para ejercer en los tribunales seglares facilitarían a los seglares la opción por Cánones, a pesar del poco efecto que, según entendemos, surtieron estas normas, especialmente en territorio ultramarino. La vacilación de las mismas, además, jugaba en favor de estos estudios. ${ }^{8}$ Una tardía real cédula de 9 de octubre de 1757, recordando la prohibición de abogar que pesaba sobre los clérigos, es la prueba evidente de que tal interdicción no se observaba. ${ }^{9}$ Con motivo de la misma, aquellos debían elevar al monarca petición para seguir abogando, pero no para recibirse ante los tribunales, puesto que esto no quedaba prohibido. En un primer momento, incluso, solicitan y reciben del virrey una dispensa temporal, con

8 Partidas 3, 6, 2, Nueva Recopilación 1, 3, 10, y 2, 16, 15, y Recopilación de Indias $1,12,1$.

9 En 1760 el monarca concede licencia a Augustín Bechi y Monterde, presbítero y catedrático de Decreto de la Universidad de México, "y Abogado de mi Rl. Auda", para que "por tiempo indefinito y sin embargo de la citada Rl. Cédula de nueve de octubre de mil setzs. zinqta. y siete pueda exercer la Abogacía hasta tanto qe. logre empleo suficiente a su desente manutención". Por esta cédula "se dispone se ge. y observe la Ley qe. prohíve a los clérigos exercer la Abogacía se hizo saver en todos los oficios qe. en adelante no reciviesen escriptos firmados de Abogados eclesiásticos bolviendo a las ptes. los qe. hubiesen recivido y no decretado". La licencia del monarca a Bechi y Monterde resultaba una ampliación de la otorgada por el virrey, que, previo informe de la Audiencia, le había concedido únicamente dos años para concluir los "muchos negocios así de aquella ciudad y sus cercanías como de varios parages remotos del reyno, Campeche, Havana y otros, y no menos perjudicial e inevitable a los interezados la retardazn. de ellos siguiéndoseles también el gravamen de haver de pagar al nuebo Abogado qe. eligiesen el travajo considerable qe. tendría en instruirse de los Pleitos"; AGN, RA, lib. 10, fol. 6v. Por otra parte, el hecho de que en el recibimiento de un clérigo después de 1757 no apareciese la petición para abogar, no creemos que significara necesariamente que no pretendiera dedicarse al ejercicio; los libros del Real Acuerdo no son muy rigurosos ni completos en sus anotaciones. 


\section{la que poder terminar las causas pendientes, para rogar después del monarca una licencia de ejercicio permanente. ${ }^{10}$}

10 Algunos de estos clérigos abogados tenían pasantes en sus despachos, lo que indica que su actividad profesional no era menor ni circunstancial. El motivo de tales peticiones era siempre el estado lastimoso en que se encontraban ante la falta de destino en la Iglesia. En ocasiones lo que solicita el presbítero no es el recibimiento, sino que no se le impida continuar en el ejercicio: "Por quanto pr. pte. del Dr. Dn. Bizente Anto [...] presvítero abogado [...] que recide en la ciud. de Mexco. y colegial del mar. de Sta. Ma. de todos Stos. de la propia ciud. se me ha representado que [...] ha obligado a los más de los natres. de aquellos dominios a solicitar su acomodo por la Iga. sin reparar en que la multitud de ordenados havía de ocacionar indispensablemte. que se quedasen alguos. sin destino pr. ser más los pretendtes. qe. los oficios y prebendas Ecccas. lo acredita la experiencia pues ay infinitos sacerdotes de loables costumbres, literatura y avilidad que se haian sin colocar y están presisados a mantenerse con mucha indecencia de que ha resultado la mr. pte. de ellos se apliquen a el estudio de los sagrados cánones y leyes con el fin de recivirse de abogados, despachar algnos. pleitos o expe dtes. para subvenir pr. este medio a sus urgencias y redimir en pte. su vejación i nesesd. como lo ha hecho el nominado Dn. Viste. Anto. de los Ríos medte. no poder soportar los gastos del citado collegio ni proporcionársele salida correspte., sin embargo de haverse opuesto a quantas piezas eclesiásticas han vacado, y que a él preste. continúa sus pretenscs., por lo que reselando qe. en cumplmto. de lo ordenado en Rl. Ceda. de nueve octre. del año de mil setos. cinqta. y siete en qe se mdó. observar lo dispto. pr. la Ley prima. títo. doce libo. primo. de la recopilan. de Indias, que prohíbe a los Eccos. la defensa de otros negos. distintos de los que comprehende, se le impedirá el que continúe en el exercicio de la abogacía; me suplicaba que en atención a lo referido fuese servdo. de permitirle que abogue indistintamente en todos los negos. que se pongan a su cuidad no obstante lo prevenido en la citada ley y R. Céda. expresda. el Rl. Despo. correspondte. pa. qe. con nigún pretexto ni motivo se le impida el uso y exercicio de esta facultad, interin se le proporciona algún destino que sufrague a su deste. manutensn $[\ldots]$ he tenido a bien el conceder, como pr. esta mi R. ceda. concedo a el nominado Dn.Vizte. Anto. de los Ríos y Herrera la lica. correspte. pa. qe. pr. ahora pueda proseguir abogando segn. lo ha practicado hta. el preste. sin embargo de lo dispuesto en la mencionada R. Cédula [...] Por tanto ordeno y mando a mi virrey de las Proas. de la N.E. a la expresada mi Rl. o qualesqra. juezes y justas. seculares y ruego encargo al M. Rdo. Arzobispo de Mexco. o su venerable Deán, y cavildo en sede vacante y a los de tribes. eclesiásticos de aquella diócesis qe. cumplan 
Así pues, la preferencia de los universitarios mexicanos por Cánones será la tónica general durante casi tres siglos, a lo largo de todo el período virreinal, acentuándose más si cabe en el ocaso novohispano. Un tiempo, este último, en el que, por el contrario, las universidades peninsulares más importantes ya estaban mostrando una clara inclinación y prioridad por los estudios legistas como formativos para los oficios públicos, hasta el punto de que solo Leyes, y no Cánones, habilitaba para el ejercicio profesional de la abogacía. ${ }^{11} \mathrm{Y}$ aunque estas reformas a favor de Leyes no alcanzaron a Nueva España, ${ }^{12}$ esta aparente contradicción práctica con el espíritu ilustrado del momento tenía, lógicamente, su explicación.

Siempre se ha dicho que, frente a la condescendencia para con los españoles americanos durante los dos primeros siglos del virreinato -más teórica que práctica, eso sí-, la dinastía borbónica del dieciocho virará decididamente y optará por un sistema de nombramientos fuertemente centralizado y en favor de los peninsulares. Se asistía así a una considerable merma en las posibilidades de aquellos súbditos en el acceso a los puestos de

y ejecuten y hagan cumplir y ejecutar puntual y efectivamente la enunciada mi Rl. determinación”; AGN, RA, lib. 10, 1762, fol. 267v.

11 Rodríguez, Polo y Alejo, "Matrículas y grados, siglos XVI-XVIII", pp. 607-663. Sobre el grado de bachiller como habilitante para el ejercicio profesional, Tormo Camallonga, El Colegio de Abogados de Valencia, pp. 183 y ss., o "La abogacía en transición”, pp. 81-122.

12 Sobre la suficiencia del grado en Cánones para el recibimiento de abogado, puede verse el interesante expediente tramitado ante la Audiencia de Quito a principios del siglo XIX, con motivo del ejercicio en la misma del canonista Víctor Félix de San Miguel. Con referencias también a las audiencias de Santa Fe de Bogotá y Lima, se hace especial hincapié en la suficiencia de estos estudios y en la necesidad de que toda disposición promulgada en y para Castilla gozase, para regir en América, de especial cédula despachada por el Consejo de Indias. No tan prolífico en información, pero igualmente interesante a estos efectos, es el expediente tramitado con ocasión de Joaquín González Barona. ANE, FE, ramo 25 (incorporación de abogados), c. 4, lib. 12 y 13 , respectivamente. 
la administración novohispana, lo que resultará especialmente evidente, mucho más tarde, en el reinado de Carlos III, hasta el extremo de que, con el objeto de impedir su promoción, se les prohibió incluso viajar a la Península para doctorarse. Podemos traer aquí a colación el cometido del visitador general José de Gálvez, sus causas y consecuencias. ${ }^{13}$ Por lo tanto, no es sólo que no se les favoreciera, sino que se les dificultaba en su ascenso profesional, incluso dentro de la misma administración eclesiástica, de siempre más proclive a las aspiraciones de los nativos de Indias. La reforma en las últimas décadas del xviII en el sistema de nombramientos para los puestos que, dentro de la Iglesia, exigían o aconsejaban una formación jurídico-canonista, alcanzó desde los cabildos catedralicios hasta las prebendas y canonjías. Como bien demuestra Aguirre Salvador, frente a las reformas del primer Borbón, que se circunscribían a los puestos civiles, las de Carlos III alcanzaban a la Iglesia de pleno. Sólo quedaron fuera los más bajos escalafones, los curatos, que se convertían, prácticamente, en el único reducto, y harto solicitado, para los novohispanos. En la justificación, que pasaba por conseguir una administración imparcial y desinteresada, obvia aludir a los intereses economicistas y recaudatorios de la Monarquía ante una élite criolla tildada en muchas ocasiones de relajada y descuidada en sus obligaciones. ${ }^{14}$ Como obvian los comentarios sobre los disgustos y antipatías que semejantes medidas tuvieron entre los americanos. ${ }^{15}$

${ }_{13}$ Informe del visitador general de Nueva España, José de Gálvez, al virrey de Nueva España, Antonio Bucareli, informándole de los asuntos que ha tenido a su cargo; AGI, Estado, 34, N. 35.

${ }^{14}$ Como punto de partida historiográfico puede verse Sánchez Santiró, "Las reformas borbónicas”, pp. 19-51, o GonZÁLEz González, El poder de las letras, pp. 68 y ss.

15 Díaz SÁnchez, "Las reformas borbónicas y la formación del descontento", pp. 127-148. 
Esta política de llamamientos restrictiva para los novohispanos removió también, y como es lógico, las entrañas de la universidad mexicana, pero, al parecer, sin que tuviera repercusión práctica en su seno, ni para el claustro ni para los estudiantes. No es necesario insistir en el tan aludido carácter irreformable de la primera casa de estudios mexicana, que se traducía, por ejemplo y tal vez a modo de protesta, en la dificultad para crear nuevas cátedras o, incluso, en la simple reforma de los horarios docentes, mucho más "benignos", obviamente, para Cánones, según palabras del propio rector. ${ }^{16}$ Ahora bien, sí se consiguió una novedad a modo de reforma, como fue la fundación a principios del xix de la cátedra de Disciplina Eclesiástica, en la que se priorizaba, y he aquí el quid de la cuestión, el estudio de la legislación eclesiástica de origen real frente a la canonista. Es decir, se estaba fortaleciendo el estudio del derecho real, sin necesidad de alterar el peso de la Iglesia ni de reformar la facultad de Leyes o priorizar sus estudios. Bastante se había tenido con la expulsión de los jesuitas como para enervar más aún, si cabe, los ánimos de la clerecía. Y además, es muy probable que el interés del monarca en Leyes ya se estuviera materializando, en mayor

16 "Para el grado de Brs. en Cánones sinco cursos tienen de probar en la Cátedra de Prima de la facultad, uno en cada año, acompañando a la asista. de ésta dos de la de Decreto, uno en la de Instituta, otro en la de Clementinas, y otro en la de Vísperas, de los quales sólo éste y el de Instituta son pr. la tarde; pero pa. graduarse de Brs. en Leyes spre. deben cursar pr. la tarde, pues a la asista. de la Cátedra de Prima del Dro. Civil en sinco años han de agregar pr. igual tpo. los cursos de la de Vísperas y dos en la de Instituta, que ambos son vespertinos; por lo qe. teniendo en sus colegios conferencias nocturnas los lunes, miércoles y viernes, quando querrían estudiarlas y buscar argumtos. pa. ellas tienen qe. asistir a la Univd. desde las tres hasta las sinco, empleados todo este tpo. en materias disímbolas muchas veces de las en qe. se versan en los colegios. $=$ Por esta razón se dedican en el tpo. de cursantes en estos a la asista. de las cátedras del Dro. Canónico, qe. no les es tan molesta y qdo. son ya pasantes sin ligación a las aulas en sus colegios entonces con dos cursos de Dro. Civil según lo establecido en la citada constitución 250 se reciven de Brs. en él”; AGN, Universidad, vol. 66, 1806, fol. 519. 
medida y para el caso de la Nueva España, con la fundación de una universidad en Guadalajara. ${ }^{17}$

Que el monarca se centrara para las reformas ilustradas -en nuestro caso, el refuerzo de los estudios legistas- en las universidades peninsulares, puede significar que era consciente de la dificultad y oposición con que, seguramente, se iba a encontrar en América, cualesquiera que fueran los términos de la reforma. Los estudios que tenemos hechos para la Universidad de San Marcos, sin embargo, cuestionan esta suposición como idea monolítica, dado que, gracias a las reformas operadas en el Convictorio de San Carlos, en Lima se observa, por ejemplo, una temprana modernización en los planes de estudios en beneficio de las preferencias realistas. ${ }^{18}$

En este sentido, nada indica que en las Indias tuviera vigencia el auto acordado de 16 de enero de 1773, por el que, como anteriormente hemos apuntado, se exigía de todo pretendiente a abogado el grado de bachiller al menos en Leyes, sin que fuera suficiente el de Cánones. Si estas reformas seculares hicieron disminuir en la Península la demanda de estos últimos grados, nada de esto sucedió en la Universidad de México. ${ }^{19}$ Sin duda, la corona seguía confiando en la Iglesia como administradora y ejecutora de sus propósitos y voluntades en América. No era cuestión, pues, de granjearse su aversión. Así, tradicionalmente se ha visto que, con la reimpresión de las constituciones de la Universidad de México en 1775, el claustro pretendía recordarle al rey cuáles eran las prerrogativas de cada instancia, teniendo en cuenta que las preferencias mostradas por los estudiantes

17 Castañeda, “La Real Universidad de Guadalajara”, vol. I, pp. 135-144. De la misma autora, "Las carreras universitarias de los graduados de la Real Universidad de Guadalajara”, pp. 261-280.

18 Tormo Camallonga, "La formación del jurista en el virreinato del Perú", pp. 199-237.

19 Aguirre Salvador, "La carrera de los graduados fuera de la universidad", pp. 63-69. 
seguían siendo las mismas de siempre, como lo iban a ser hasta el mismo momento de la independencia. Unas preferencias que venían determinadas, claro está, por las disponibilidades de estudio y colocación posterior. ${ }^{20}$

Sin embargo, tomando estos presupuestos - muy globales, eso sí- como punto de partida, y dando un giro radical a las hipótesis o conclusiones que hasta ahora podríamos inferir de todo lo expuesto, los cargos de más alto rango en las instituciones asentadas en la Nueva España -las audiencias-, y para cuyo nombramiento el monarca supuestamente priorizaba, según el momento, a los peninsulares o a los criollos, creemos que eran tan reducidos en su número, que el acceso a los mismos difícilmente podría conducir a los escolares naturales a decantarse por el estudio, bien de Leyes, bien de Cánones. En conjunto, y según Burkholder y Chandler, hablamos de 76 plazas permanentes para toda América en 1687, teniendo en cuenta, además, el complejo sistema de ascensos y que las aspiraciones de estos individuos tenían, como aclaran estos autores, unos evidentes límites geográficos. ${ }^{21} \mathrm{No}$ creemos, pues, que el atractivo de estas plazas fuera una cuestión tan decisiva en la elección por el estudiante de una facultad u otra, con bandazos tan pronunciados en los años del cambio dinástico que aquí analizamos.

Al mismo tiempo, la necesidad de letrados que tenía el virreinato a finales del siglo XVII y principios del XVIII iba a ser la misma de siempre, al menos para el despacho de las causas

20 GonzÁlez GonzÁlez, "La reedición de las constituciones universitarias de México”, pp. 57-108. Algunas leves reformas se observan en Nueva España a principios del siglo XIX, pero afectaron mayormente a otros centros de estudios; Tormo Camallonga, "La renovación de la Jurisprudencia”, pp. 317-336.

21 En concreto, y para México, ocho oidores, cuatro alcaldes del crimen y dos fiscales; para Guadalajara, cuatro oidores y un fiscal. "Criollo natural” era el nacido en el territorio de la audiencia en cuestión; sólo “criollo” era el nacido en la demarcación de otra audiencia indiana. Burkholder y Chandler, De la impotencia a la autoridad, p. 14. 
particulares. Nada iba a cambiar en este sentido y, vista la concurrencia de contenidos entre los estudios de Cánones y Leyes, no parece que hubiera motivos para que se asistiera a un traslado tan considerable de las matrículas a favor de los estudios legistas, máxime si tenemos en cuenta, como ya hemos dicho, que los puestos para los que, en su caso, se podría priorizar la formación en Leyes tampoco ofrecían muchas más posibilidades.

En definitiva, pues, deberíamos cuestionar la repercusión de la política regia de nombramientos para los novohispanos -restrictiva o generosa según el momento- sobre las aspiraciones y preferencias de sus estudiantes juristas, en especial en el tránsito del siglo xvII al xviII, y también de éste al xIx. Si con los últimos Borbones tal vez sí pudiéramos pensar que se estaba reforzando el papel ya de por sí preeminente de Cánones, no creemos que las similares medidas restrictivas que, en su caso, había adoptado Felipe $\mathrm{V}$ ocasionaran la debacle en los estudios legistas, que habían experimentado un ascenso igualmente sorprendente durante los últimos años del reinado de Carlos II. Dicho de otra manera, la realidad de la Universidad de México promete mucha más riqueza en detalles de lo que ofrecen unas tendencias que, en la simplificación de sus conclusiones, suelen oscurecer particularidades y matices que son reflejo y a la vez instrumentos de integración de tantos reajustes y acomodaciones temporales.

\section{UN CAMBIO TANGENCIAL, PERO EVIDENTE}

Desde la consabida primacía de Cánones, en las últimas décadas del siglo xvir se asistirá a un importante aumento en el número de escolares que optaban por Leyes. Son unos años que transcurren entre la decadencia de la autoridad real en Indias, en bancarrota política y económica según lo ha visto la historiografía, y el rearme de poder o recuperación de la iniciativa por parte del monarca. Es un periodo breve en toda una tendencia uniforme, que desde la perspectiva de lo que había sucedido hasta entonces, 
como de lo que volverá a ocurrir más tarde, podemos calificar, sin duda, como diferente y transitorio, en la medida en que ambas facultades llegarán casi a equipararse en cuanto a las preferencias de sus estudiantes. Es más, en algunos años se ganan más cursos en Leyes que en Cánones, algo realmente excepcional. ${ }^{22}$

Estamos ante una realidad, llamémosle circunstancial, para la que, y según creemos, todavía no contamos con causas que la expliquen en su totalidad de manera convincente. En ningún momento como durante estos años son tantas las referencias que sobre Leyes podemos encontrar en los Libros de Gobierno de la Real Universidad de México. Cuestiones diversas sobre matrículas y cursos, sus dispensas y convalidaciones, sobre los ejercicios académicos o los grados, son ahora tan abundantes para Leyes como para Cánones, cosa que no hemos podido encontrar en ningún otro momento, ni anterior ni posterior. ${ }^{23}$

En las siguientes gráficas podemos ver el número de cursos ganados por los estudiantes en ambas facultades. ${ }^{24}$ En la primera de ellas se aprecia la tan aludida tónica general de la universidad mexicana a favor de Cánones; una preeminencia sostenida durante todo el período colonial. En la segunda vemos la particularidad del periodo concreto del que hablamos, a favor de Leyes, y para el que iremos presentando un ensayo de interpretaciones.

22 Tenemos constancia de 58 cursos de Leyes frente a 49 de Cánones en 1691, 61 frente a 39 en 1692, 48 frente a 37 en 1693, 50 frente a 36 en 1694, 58 frente a 38 en 1695, 36 frente a 27 en 1698, 62 frente a 61 en 1707, 82 frente a 69 en 1710, y 87 frente a 80 en 1721; AGN, Universidad, vols. 452 a 457.

23 En numerosas ocasiones se apunta a que muchos estudiantes optan por Cánones frente a Leyes por los mejores horarios de aquella facultad (fol. 434), aunque también parece haber algún problema con la coincidencia de horarios para Artes y Cánones (fol. 562v.). Por otra parte, son habituales los cambios de matrícula de una facultad a otra por, según se dice, deseo de los padres; AGN, Universidad, Libros de Gobierno, vol. 46, fols. 136, 280 o 390.

24 Sobre el sentido y significado de los cursos dentro de la vida académica, su obtención y su papel en la consecución del grado, véanse Tormo CAMALLONGA, "No sólo burocracia”, pp. 449-473; y "En la parte que se pueda, pp. 101-138. 
Gráfica 1

CURSOS GANADOS 1635-1810

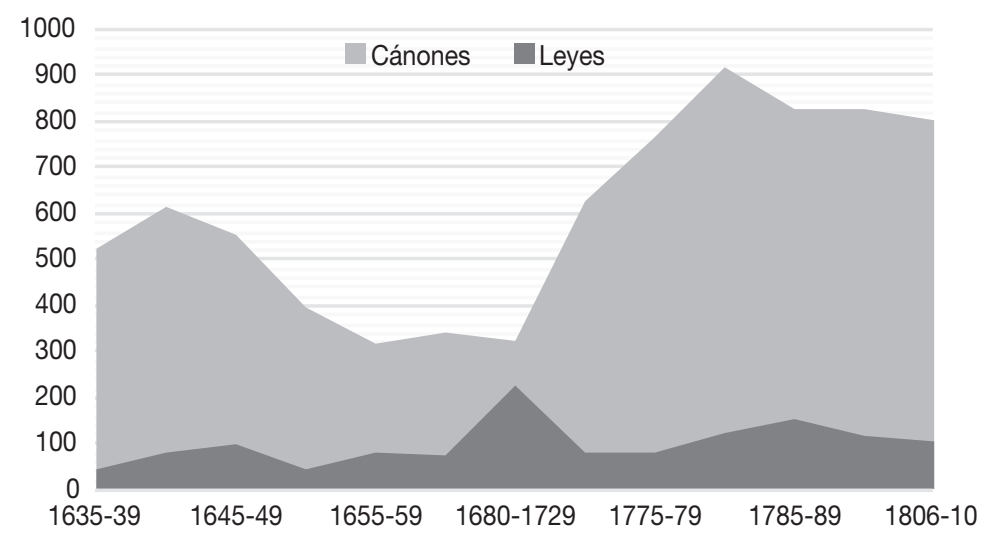

Fuente: AGN, Universidad, vols. 438-440, 447-450 y 457.

\section{Gráfica 2 \\ CURSOS GANADOS 1680-1729}

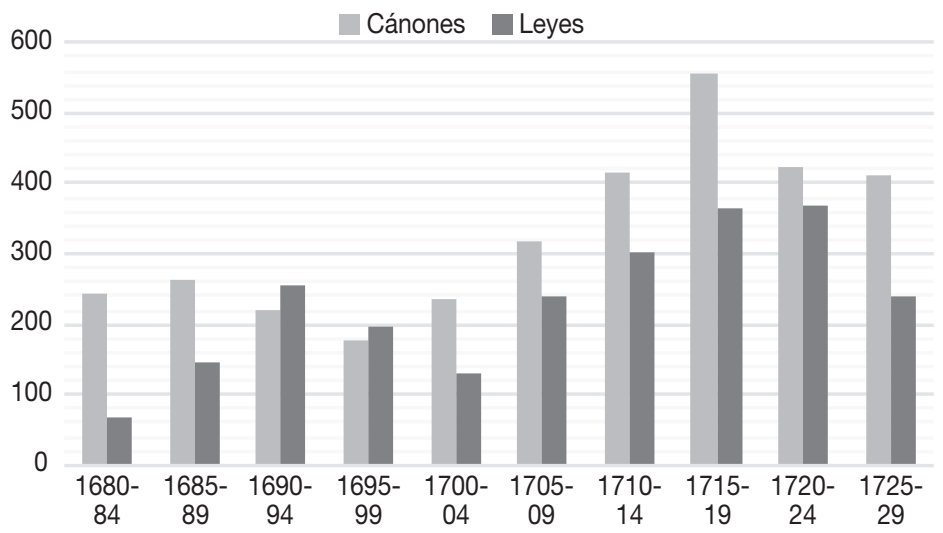

FUENTE: AGN, Universidad, vols. 436 y 451-456. 


\section{DE LAS POSIBLES INTERPRETACIONES}

Una de las explicaciones ante la realidad circunstancial de la segunda gráfica, sería la suposición de que, a partir del año 1687 , los españoles americanos vieran aumentadas sus posibilidades de acceder a una plaza en las audiencias indianas, dado que ahora -con una fuerte inversión pecuniaria, eso sí- podrían comprar estos cargos. En nuestro caso, estamos hablando de las audiencias de México y Guadalajara. Lohmann Villena, centrándose en la Audiencia de Lima, ha demostrado que el cambio no admite discusión ni en el Perú ni en la Nueva España, con una abrumadora mayoría, respectivamente, de los núcleos peruanos y novohispanos a partir de ahora y hasta el último cuarto del xviıI, con el nombramiento de José de Gálvez como secretario de Estado de las Indias. ${ }^{25}$ De manera que del nuevo sistema de nombramiento para estas altas autoridades, tal vez los novohispanos dedujeran un posible cambio de rumbo, una cierta reforma que podría pasar quién sabe si por un mayor desarrollo de la administración civil, desde las audiencias hasta los ayuntamientos, cuyos cargos, los de estos últimos, por no recaer por lo general en individuos letrados, necesitaban del asesoramiento de estos graduados. Es una actitud austracista cuyos efectos prácticos no parece que pudieran ser expeditos, pero que tal vez sí repercutió de inmediato en la universidad y en las expectativas de sus estudiantes.

En este punto, es importante destacar que el hecho de ganar cursos de Leyes durante este periodo no era como complemento a los de Cánones -lo que había sido la tónica general a lo largo del virreinato, y lo continuará siendo después de este paréntesis

25 Lohmann Villena, Los ministros de la Audiencia de Lima, pp. xcvii y ss. y c. Desafortunadamente, no podemos hacer estudios universitarios comparativos con los estudiantes peruanos puesto que, a estos efectos, la ausencia de documentación para la Universidad de San Marcos es absoluta. 
temporal-, sino que tenían sustantividad propia. Veámoslo más detenidamente.

Sabemos que las dos facultades de Derecho tuvieron tradicionalmente la consideración de hermanas o símbolas, y no sólo en la Nueva España, sino en toda la Monarquía. Al margen de las cátedras propias, fundamentalmente Decreto y Decretales para Cánones, y Digesto y Código para Leyes, ambos planes de estudios se erigían desde el adiestre en la Instituta, como obra de la compilación de Justiniano dedicada esencialmente a la enseñanza del Derecho. Era la cátedra que dominaba ambas facultades. Por lo mismo, todos compartían metodología docente, lo que permitía que el estudiante que obtenía el grado de bachiller en una de estas facultades pudiera hacerlo también en la otra, con tan sólo dos cursos más. Y es en este punto en donde los estudios de Leyes solían ser accesorios a los de Cánones. Es el bachiller in utroque iure. Son muy significativas al respecto las siguientes palabras del claustro de la Universidad de México, todo indica que de los años cuarenta del siglo XviII:

Es la facultad de Cánones tan inmensa, que no ay otra más dilatada, tiene tanta unión con las Leyes que no se puede saber sin plena noticia de ellas; en defecto de texto canónico deben los Juezes ecclesiásticos determinar los negocios por las leyes, según el capítulo 1: de novi operis nunciatone, cum concordantibus; por esso nuestras constituciones ordenan que los canonistas no sólo cursen Decretales, Decreto, Clementinas y Sexto, que es todo el dro. Canónico, sino también la cáthedra de Instituta, que es Compendio de las leyes Cesáreas. ${ }^{26}$

Así pues, y dada la incuestionable primacía de los estudios canonistas, la mayoría de los cursos ganados en Leyes lo eran por parte de estudiantes que ya eran bachilleres en Cánones. Y

26 AGN, Universidad, Libros de Gobierno, vol. 52, fol. 56. 
de ahí que la mayoría de matrículas formalizadas para Leyes lo fueran de primero o segundo, siendo muy escasas las matrículas de cursos superiores. Realmente, eran unos estudios accesorios a Cánones y cuya razón de ser estribaba, fundamentalmente, en el prestigio que confería a su titular el ser doblemente graduado. Por lo tanto, y teniendo que estudiar al menos cinco cursos, muy pocos iban a ser los que optaran porque el de Leyes fuera su primer grado.

Sin embargo, en estos años de finales del siglo xvir y principios del xvIII se observa cierto equilibro entre los cinco cursos legistas, con una mayor proporción, si se quiere, en los primeros, descendiendo, lógicamente, a medida que se asciende en ellos, de la misma manera que ocurría en Cánones. Lo que queda claro es que hay una evidente continuidad en la opción del estudiante legista, que incluso en ocasiones decidía que fuera el de Cánones el grado secundario. Nada de eso vemos en ningún otro período, ni anterior ni posterior.

\section{Gráfica 3}

CURSOS DE LEYES

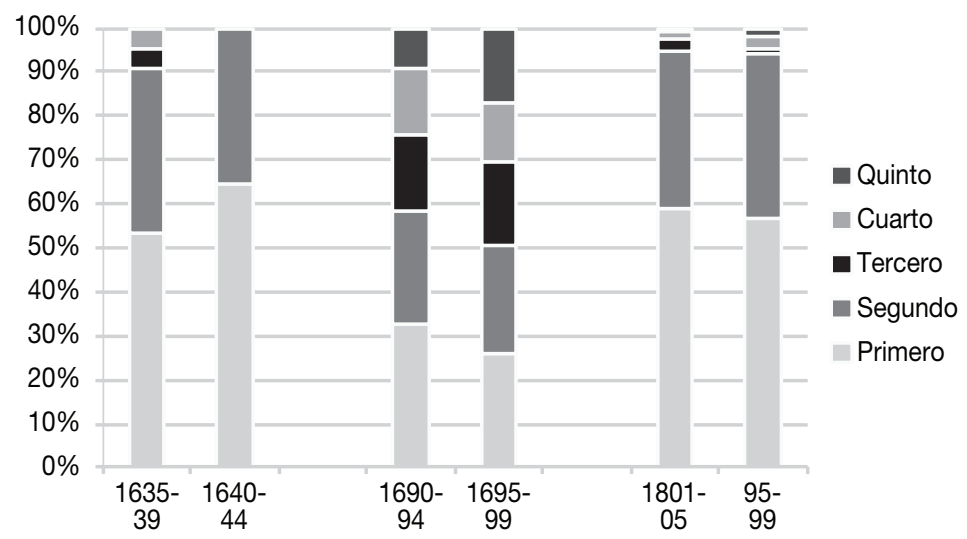

FuENTE: AGN, Universidad, vols. 436, 447, 448, 452 y 457. 
Como era de esperar, la transitoria apetencia por Leyes se manifestará, además de en las matrículas y en los cursos ganados, en los grados, lo que, a su vez, se reflejará en el posterior recibimiento como abogado ante los tribunales. ${ }^{27}$ En cuanto a los grados de bachiller, se aprecia el sustancial aumento de legistas en el tránsito de siglos y su posterior y definitiva decadencia, en concordancia con los cursos ganados. ${ }^{28}$

\section{Gráfica 4 \\ GRADOS DE BACHILLER}

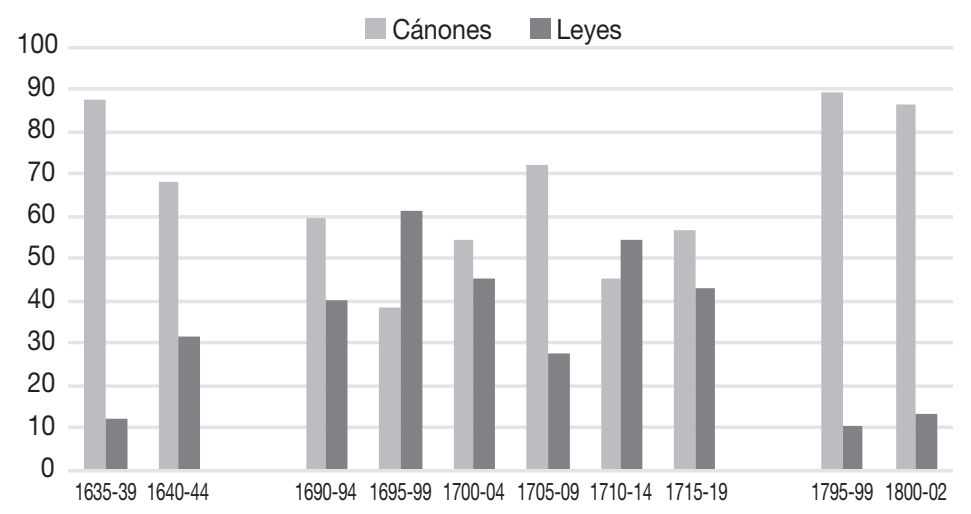

FuENTE: AGN, Universidad, vols. 252, 253, 254, 258, 273, 274 y 295.

Título XXIV del libro segundo de la Recopilación de Indias, "De los Abogados de las Audiencias y Cancillerías Reales de las Indias", Partidas 3, 6, 13, y Nueva Recopilación 2, 16, 1 (Nov. Recop. 5, 22,1). Es posible que en un principio sólo pudieran ejercer en todos los tribunales de la monarquía los recibidos en el Supremo Consejo, pero con el tiempo se admitió a todos los recibidos en cualquier chancillería o audiencia; el auto acordado de 23 de junio de 1722 parece confirmarlo (auto 2, 16, 10, edición de 1775, Nov. Recop. 2, 19, 3). ${ }^{28}$ Los libros de grados están ordenados alfabéticamente según el nombre, que no el apellido, del graduado. Dado que el libro para Leyes de 1576 a 1700 no contiene más que los graduados de la letra A a la I, nos hemos ceñido 
Finalmente, y como hemos dicho, el número de legistas que durante estos años se examinaron y aprobaron como abogados en la Audiencia de México es claramente superior al de canonistas. Esto es algo realmente singular, pues su número era, por lo habitual, testimonial, más todavía que el de estudiantes. Aunque la falta de libros del Real Acuerdo y el hecho de que muchos de ellos no parecen estar completos nos impide hablar de manera categórica, la siguiente gráfica nos vale como referencia más que orientativa. ${ }^{29}$

\section{Gráfica 5}

ABOGADOS RECIBIDOS ANTE LA AUDIENCIA

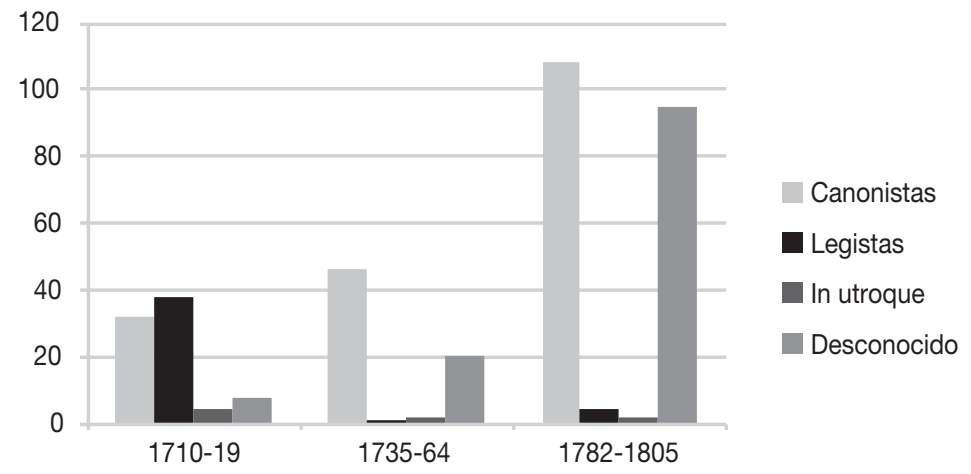

FuENTE: AGN, Real Acuerdo, libros 2-B.1 a 21.

-restringido, si se quiere- en todos los casos a estas series alfabéticas. No creemos que un estudio para todos los apellidos pudiera ofrecer resultados muy diferentes. Aguirre Salvador, El mérito y la estrategia, pp. 78 y 395.

${ }^{29}$ Hemos considerado como graduados en cada una de las facultades no sólo a los que expresamente aparecen como tales, sino también a los que, sin referencia al grado, se dice que son pasantes en la facultad de Leyes o Cánones. La elevada cifra de desconocidos para el periodo 1782-1805 se debe, a nuestro entender, a la superflua determinación de la facultad, dando por supuesta la norma en favor de Cánones. 
Con todas estas referencias, creemos que, si bien la política de venta de cargos abierta en 1687 podría explicar una cierta rapidez en el cambio de elección por parte de los escolares, no puede ser la causa que la explique con semejantes magnitudes. Es más, no resulta sencillo encajar esta hipótesis con las fechas de referencia, pues parece que las primeras y escasas ventas de plazas para las audiencias novohispanas -salvo el caso aislado de Francisco Anguita Sandoval, de 1700-, se retrasan, para la de México en concreto, hasta la tardía fecha de 1707, cuando el empuje de Leyes era ya más que evidente. ${ }^{30}$ Por otra parte, y esto es importante subrayarlo, la política de venta de cargos públicos estaba beneficiando mayoritariamente a los peruanos, pero no tanto a los novohispanos, ${ }^{31} \mathrm{y}$, para más inri, fue una estrategia real que no dejó de ser en todo momento dubitativa y oscilante; de hecho, y por un cambio de intereses del monarca, el referido Anguita Sandoval pierde el cargo tan pronto como 1701. Así pues, no creemos que semejante incertidumbre fuera compatible con tan firme cambio de tendencia en el enfoque y en las esperanzas de los estudiantes. Debemos tener en cuenta, además, y esto también es muy importante, que para acceder a una de estas plazas togadas, en ningún momento, ni ahora ni tampoco con las reformas ilustradas de finales de siglo para las universidades peninsulares, ni el monarca ni el Consejo de Indias relegó a los graduados de Cánones en favor de los de Leyes, siendo además que, en su mayor parte, eran titulados en ambos derechos y doctores. ${ }^{32}$

\footnotetext{
30 Burkholder y Chandler, De la impotencia a la autoridad, p. 48.

31 Hay autores que no coinciden con Bukholder y Chandler respecto a la supuesta discriminación de los criollos en la política de nombramientos de los Borbones. Es el caso de Lohmann Villena para el virreinato del Perú y que, con palabras duras y contundentes, califica este postulado doctrinal como de verdadero "ripio histórico". Solo a partir de los años sesenta el porcentaje de criollos disminuye, de manera, eso sí, incontenible. Véase LoHmann VILLENA, Los ministros de la Audiencia de Lima, pp. xxv y ss.

32 Burkholder y Chandler, Biographical Dictionary.
} 
Insistimos en que, por encima de cualquier otra consideración, el montante de plazas de oidor, alcaldes del crimen y fiscales, junto con las de los gobiernos mayores, no creemos que pudiera alcanzar, ni de lejos -y ni siquiera contando con las plazas de supernumerarios-, una cifra suficientemente elevada como para justificar convincentemente este marcado cambio de tendencia. O sea, como para que los graduados albergaran fundadas esperanzas de encontrar en la administración civil las posibilidades que hasta entonces sólo les había ofrecido la carrera eclesiástica. A esto añadimos que los altos cargos en las audiencias no tenían consideración de "vendibles y renunciables”, por lo que no podían ser heredados ni enajenados. Era una apuesta del "comprador" sobre su propia longevidad, para la que no creemos que pudiera haber semejante prole de aspirantes. ${ }^{33} \mathrm{Y}$ eso sin considerar las protestas que tanto desde la Península como desde Nueva España se levantaban contra esta práctica; a nuestros efectos, desde las mismas audiencias de México y Guadalajara. Por lo tanto, debemos cuestionarnos hasta qué punto la toga en estos más altos escalafones de la judicatura real era, en verdad, la mayor de las aspiraciones factibles que podía albergar cualquier jurista laico. ${ }^{34}$

Bien es cierto que también se estaban poniendo en venta más cargos, inferiores o municipales, y mucho más numerosos, como corregidores y regidores, alcaldías mayores y menores, protectores de indios, jueces visitadores, notarios y demás oficiales reales. Hablamos, ahora sí, de "oficios vendibles y renunciables". ${ }^{35}$ A estos puestos se unieron después otros relacionados con los asuntos de hacienda y tributos, que también se estaban vendiendo, o sobre los que, por medio de subasta, se podían beneficiar los indianos desde 1655, y mucho más claramente a

33 Burkholder y Chandler, De la impotencia a la autoridad, p. 34.

34 Aguirre Salvador, “¿Abogados o clérigos?”, pp. 85-149.

35 SAnz TAPIA, “La justicia en venta”, pp. 63-90. 
partir de 1680. Es el caso de los "oficiales reales", como los factores, contadores de tributos, tesoreros y veedores de Caja Real. ${ }^{36}$ Hablamos, pues, de muchos otros oficios dentro de una administración real para cuyo desempeño, aunque no se exigía, sí se recomendaba la posesión de un grado. Y para todos ellos, tal vez, sí se estaban considerando positivamente los estudios de Leyes o, al menos, no se estaba priorizando a los canonistas. Es algo que no podemos más que sugerir, dada la heterogeneidad de situaciones y que no disponemos de ningún estudio al efecto.

Pero, y en contra de esta última suposición, esta política de venta de cargos menores no es propia de estos momentos, ni mucho menos, sino que había empezado ya con Felipe II, alcanzando a ser masiva con Felipe IV, incluso en contra de la opinión del Consejo de Indias. Además, se vendían mediante acuerdos particulares y, lo que es mucho más significativo, en ningún momento había hecho peligrar la absoluta primacía de Cánones. ${ }^{37}$

Con la entrada del siglo xviII se estabilizaron de nuevo las ventas de los altos cargos públicos, cuando no disminuyeron, lo que sí se ajustaría al documentado repunte canonista. ${ }^{38}$ Como siempre, mientras que el graduado en Cánones podría labrarse una carrera dentro de la Iglesia, el legista lo tendría más complicado dentro de la administración civil, por ser ésta más reducida,

\footnotetext{
${ }_{36}$ Muro Romero, “Instituciones de gobierno”, pp. 163-231.

37 Burkholder y Chandler, De la impotencia a la autoridad, pp. 33 y ss.

${ }_{38}$ Muchas de estas cifran están dadas para el reino del Perú, pues muy poco de lo que en este sentido estamos diciendo se ha estudiado para la Nueva España, por lo que deberíamos comprobar los posibles paralelismos o diferencias. Sanz Tapia, "Provisión, beneficio y venta de oficios americanos de Hacienda (1632-1700)", pp. 145-172, así como "Provisión y beneficio de cargos políticos en Hispanoamérica (1682-1698)”, pp. 107-121. En este último estudio sí se destaca el elevado número de estas ventas en México (pp. 117-119). Del mismo autor, "Aproximación al beneficio de cargos políticos americanos, pp. 147-176. En cualquier caso, tendríamos que analizar los méritos presentados por los adquirentes de estas plazas o cargos. Tampoco podemos subestimar el hecho de que muchas de estas plazas eran compradas por peninsulares.
} 
además, claro está, de tenerlo más difícil en la eclesiástica. Aun así, la política de cuño centralista de los Borbones no daría tan rápidamente fin a este episodio que hemos adjetivado como circunstancial. Los desastres en la Península ocasionados por la Guerra de Sucesión no permitían rechazar ningún ingreso, como tampoco estaba de más asegurarse fidelidades y rectitud en el proceder. Pero no era momento para cambios estructurales. Es lo que algunos autores -Burkholder y Chandler-llaman la etapa de la impotencia del poder real.

Este retorno a favor de Cánones, aunque sin ser tan marcado como el de años antes a favor de Leyes, se intensificará de manera nítida cuando, en la década de los años veinte, se produzca otro vaivén en la política de nombramiento de las plazas togadas a favor de los peninsulares. El centralismo borbónico se estaba imponiendo, y al parecer mucho antes en la Nueva España que en el Perú. Una situación que, de nuevo, nos obliga a considerar seriamente la conexión que pudiera existir entre togas y la disyuntiva Cánones-Leyes. ${ }^{39}$ El veto a los novohispanos en el acceso a estos cargos que algunos han creído ver que requerían, o al menos aconsejaban, el grado en Leyes, acentuaría otra vez la predilección de los estudiantes novohispanos por Cánones, asumiendo, ya definitivamente para todo lo que quedaba de virreinato, que sólo la administración de la Iglesia podría ofrecerles una cierta seguridad.

Esto último es, sin duda, cierto. Sin embargo, se mantienen las dos objeciones de siempre: en ningún momento se ha demostrado que para las plazas de las audiencias fueran preferidos los legistas a los canonistas y, por otra parte, debemos cuestionarnos hasta qué punto, vista la anterior nitidez del cambio de tendencia a favor de Leyes, los estudiantes habían confiado decididamente, quién sabe si inocentemente, en un hipotético y futurible crecimiento de la Administración civil y de sus

39 Aguirre Salvador, El mérito y la estrategia, p. 399. 
oportunidades en ella. De hecho, si la causa del retorno a la opción por Cánones fue consecuencia de la visita de Francisco de Garzarón, de la que a continuación hablaremos, parece que a los estudiantes les llevó tiempo asimilar que su futuro profesional debía pasar, ya de manera incontestable, por la administración eclesiástica. Si las graves consecuencias de la referida visita sobre los cargos de justicia se aprecian ya en 1719, la alta matrícula de Leyes se prolonga a lo largo de toda la década de los años veinte. ${ }^{40}$ Además, ¿̇hasta qué punto eran conscientes los estudiantes y sus familias -siendo que la opción no era tanto personal como doméstica- de las estratagemas de la administración del rey y de sus voluntades, así como de la solidez en su determinación?

Como resumen de este apartado, y admitiendo que la política de venta de plazas togadas estuviese relacionada con el cambio de preferencias en los estudios de Derecho, albergamos serias dudas de que la pudiera explicar en su totalidad.

\section{LA VISITA DE FRANCISCO DE GARZARÓN}

Detengámonos en un hecho que podría ofrecernos una explicación al final de este paréntesis legista, en la incuestionable primacía de los estudios y estudiantes canonistas, tanto en la Universidad de México como en su Audiencia. Aunque no hemos encontrado todavía una relación de causalidad directa entre ambas cuestiones, nos resulta muy sospechosa la coincidencia

${ }^{40}$ Eso sí, en los últimos años de la década ya se aprecia un evidente y definitivo declive de Leyes. Algo similar ocurre en cuanto a los cursos ganados. Para 1720 hemos contabilizado 102 de Cánones frente a 79 de Leyes; en 1721, 80 frente a 87; en 1722, 81 frente a 67; en 1723, 82 frente a 71; y en 1824, 79 frente a 66. En el segundo quinquenio de la década el descenso en Leyes es, de nuevo, más acentuado: para 1725 se contabilizan 86 probanzas y juramentos en Cánones frente a 48 en Leyes; para 1726, 103 frente a 62; para 1727, 78 frente a 48; para 1728, 80 frente a 43; y para 1729, 65 frente a 37. AGN, Universidad, vol. 456. 
de fechas y el tratarse ambas de temáticas conectadas, lo que nos obliga a tener seriamente en cuenta esta posibilidad.

Por real cédula de 21 de diciembre de 1715, Felipe V ordenaba al inquisidor del reino, Francisco de Garzarón, la realización de una visita a la Real Audiencia de México. El motivo fundamental era comprobar el funcionamiento de la administración de justicia, para terminar con los excesos y defectos de los que, se tenía constancia, adolecía la Audiencia. En realidad, y por encima de una situación que pudiera ser coyuntural, lo que buscaba el monarca era fiscalizar a unas autoridades de cuya confianza dudaba, a efectos de "que reforméis y quitéis todos los abuzos introduzidos y practicados con nombre de estilos, siendo como son realmente corruptelas". ${ }^{41}$

Siempre se ha dicho que esta visita era consecuencia de la corrupción que había conllevado la política de venta de cargos de los años anteriores, y en la que se había desatendido gravemente el ascenso por sólo méritos o el mismo escalafón. ${ }^{42} \mathrm{Y}$ a pesar de que, con todos los nombramientos posteriores, la visita no terminaría hasta la muerte de Garzarón en 1727, sus primeras observaciones, ciertamente relevantes, ya están redactadas el 9 de agosto de 1720 con la remisión al Consejo de Indias del oportuno informe.

La cuestión es que eran muchos y variados los motivos de queja; desde la flagrante e injustificable violación del secreto en la votación de los acuerdos, a la falta de severidad y austeridad que debía envolver toda actuación oficial y pública de los magistrados, pasando por los retrasos y las continuadas estafas en los pleitos de y sobre los indios, las irregularidades en el cobro de aranceles, o el completo desorden en el proceder de

${ }^{41}$ Sobre la real cédula véase Baeza Martín, "La condena de españoles", pp. 449-474, p. 452, y MARTIRÉ, “Algo más sobre Derecho Indiano”, p. 257. ${ }_{42}$ Podemos ver interesantes matices de esta idea en García García, "Corrupción y venalidad en la magistratura mexicana", pp. 13-37, o en "La lucha contra la corrupción judicial y gubernativa en Nueva España”, pp. 337-362. 
los subalternos. Y todo ello en un contexto de abandono social y desprestigio de la autoridad, tanto civil como eclesiástica. $\mathrm{Y}$ aunque las amonestaciones de la superioridad para con las audiencias eran generalizadas en toda la Monarquía, la que se recibe en la de México, en mayo de 1722, datada en 13 de diciembre del año anterior, era especialmente ruborosa por su intensidad y extensa por afectar a todos sus agentes. Respecto a los magistrados, abogados y relatores de la Audiencia, Garzarón mencionaba, respectivamente:

La poca observansia de quanto con madura reflecçion previenen las Leyes de esos y estos Reinos; sino también su entero abandono con grave menoscabo de mi Real autoridad, comunicada a esa Audiensia, y no menores perjuizios a la causa pública por la mala administración de justizia [...] En quanto a los Abogados de esa Audiensia, se ha reconozido el abuso de tolerarles la defensa de los pleitos en estrados no estando aprovados por el Acuerdo y sin tener título en forma; por lo qual os ordeno, que sin los referidos requisitos no les permitáis la defensa en estrados, y el que sin ellos lo hiziere quede suspendido desde luego de su Ministerio [...] Y haviendo bien fundadas notizias de que algunos relatores de esa Audiensia no están resevidos de Avogados, y son enteramente ignorantes para tan peligroso y delicado empleo en que los Juezes defieren para la administrasión de Justicia: Mando que luego y sin la menor dilazión hagáis un rigoroso examen de la habilidad y sufiziensia de ellos, y que sólo queden en exerzizio los que se hallaren con los requisitos que piden las leies, excluiendo los inháviles y dándome quenta de los qe. lo fueren pra dar providensia. ${ }^{43}$

Aunque la visita de Garzarón entronca con la fructífera práctica de controles que en los siglos anteriores habían ejecutado los Habsburgo, dada la suma relevancia que, junto con la fe,

${ }^{43}$ AGN, RA, vol. 4, exp. 33, fols. 174 ss. 
concedían a la administración de justicia, ${ }^{44}$ también la debemos incluir, decididamente y como hemos dicho, dentro de una etapa de marcada desconfianza del primer Borbón hacia la administración novohispana en general, y no sólo la gubernativo-judicial, sino también la económica, la Real Hacienda. ${ }^{45}$ En verdad, no podía haber motivación política ni mucho menos hipotéticas represalias ante una Nueva España que sólo le había mostrado fidelidad en la contienda sucesoria. Se trataba únicamente de la corrección de un proceder que se consideraba impropio por viciado, en la búsqueda de una administración más ágil y responsable, más eficaz y, cómo no, más provechosa. Y partiendo, eso sí, de que el nuevo rey no se sentía obligado respecto a la tradición de los Habsburgo para con los americanos.

A efectos prácticos, el resultado del examen de Garzarón se saldó, además de con las correspondientes multas, con la suspensión e inhabilitación de funciones a once de los dieciocho magistrados de la Audiencia. Los depuestos eran en su gran mayoría novohispanos y de los que, en su momento, habían comprado el cargo. A partir de ahora, y como bien dicen Burkholder y Chandler, "los letrados americanos, cuyas esperanzas de ser favorecidos con un empleo en su provincia de origen habían sido alimentadas en la época de auge de la venta de cargos, cayeron presa de una amarga desilusión". ${ }^{46}$ En opinión de los que han estudiado este tema, los resultados de

\footnotetext{
${ }^{44}$ Arregui Zamorano, La Audiencia de México según los visitadores.

45 Escamilla, Los intereses malentendidos, pp. 187 y ss. y 216 y ss. Medina, Historia del Tribunal del Santo Oficio de la Inquisición en México, p. 383. Gómez Gómez, Las visitas de la Real Hacienda novohispana. En cuanto a los oficiales de la Real Hacienda, el 2 de febrero de 1716 es nombrado para una comisión Prudencio Antonio de Palacios; véase, de la misma autora y obra, pp. 107 y ss.

${ }^{46}$ Burkholder y Chandler, De la impotencia a la autoridad, pp. 62 y 67. Insistimos en el cuestionamiento de la relación que tradicionalmente se ha establecido entre venalidad y corrupción. García García, "Corrupción y venalidad", pp. 25 y ss.
} 
la visita imprimieron un cambio de rumbo que ya no conoció vuelta atrás. Con esta política de nombramientos mucho más controlada e intervencionista, se ponía fin a las aspiraciones de los novohispanos de acceder a la alta magistratura; quién sabe si a los proyectos iniciados en el ocaso del régimen austracista en favor de una administración civil más poderosa.

No obstante, y volviendo a nuestros recelos, no resulta sencillo deducir, como hacen algunos de estos autores, que, como consecuencia directa de esta nueva política de nombramientos, desaparecería para los escolares juristas el atractivo por el estudio de Leyes, recuperando Cánones su tradicional protagonismo. En cualquier caso, el declive en los estudios legistas no sería abrupto en un primer momento, consecuencia, tal vez, de los titubeos en las decisiones reales y, tal vez también, de que durante los años siguientes se asistió, a pesar de todo, a una cierta revitalización de la Audiencia; aumentan sus alcaldes del crimen y oidores, con tres salas civiles, así como sus salarios, con la intención de desatascar el ingente trabajo acumulado desde años atrás. De ahí, posiblemente, que los escolares ya iniciados en Leyes no desistieran tan fácilmente de su voluntad inicial. Pero era cuestión de tiempo, y no de mucho, y, lógicamente, es bien probable que se notara antes en las matrículas que en los grados.

Si entre 1691 y 1700, y en oposición a la tendencia histórica, los cursos ganados en Leyes superan a los ganados en Cánones -437 frente a $377-,{ }^{47}$ a partir de principios de siglo Cánones se recupera y vuelve a superar a Leyes, tanto en matrículas como en grados, aunque con una diferencia mucho menor que la acostumbrada. Esta diferencia se mantiene más o menos estable, reduciéndose en los primeros años de la década de 1720, tal vez con motivo de la señalada revitalización de la Audiencia. Sin

47 En 1692 se ganan 39 cursos de Cánones frente 61 de Leyes, 38 frente a 58 en 1695, 57 frente a 61 en 1707, 69 frente a 82 en 1710, y 80 frente a 87 en 1721. En cuanto a los grados de bachiller, Aguirre SALVAdor, El mérito y la estrategia, pp. 78 y 395. 
embargo, y asumiendo que esta revitalización fuera la causa de este aumento legista puntual, el nombramiento de nuevos cargos había recaído a favor de juristas exclusivamente peninsulares, sin lazos personales con la sociedad novohispana, algo que continuaba férreamente perseguido por la casa de los Borbones, $\mathrm{y}$ que se mantendrá durante todo lo que quedaba de virreinato. ${ }^{48}$

Lo que parece quedar claro es que, tras la visita de Garzarón, los estudiantes mexicanos no podían esperar ninguna mejora en sus posibilidades dentro de la administración indiana. Si bien el real decreto de 31 de marzo de 1720 insistía, además de en la necesidad de licencias varias, en la prohibición del acceso a las plazas de las audiencias para los naturales del Perú y Nueva España, con motivo de la resolución en 1727 de un caso judicial sobre obrajes, se introduce la duda razonada sobre si dicha limitación se extendía a otros muchos cargos civiles inferiores, como los de gobernador, oficial real, alcalde mayor, corregidor, etc. Está claro que semejante confusión en absoluto beneficiaría la opción por Leyes. ${ }^{49}$

Así pues, todo indica que en los años treinta Cánones recupera, y en la misma medida, el absoluto protagonismo de antaño. ${ }^{50}$ $\mathrm{Y}$, aunque para las siguientes décadas no podamos hacer estudios comparativos, puesto que no se conservan los libros de cursos, para mediados de la centuria el estudio de Leyes refleja nítidamente su histórico carácter subsidiario y residual a favor de una carrera mucho más prometedora, como era la que se pudiera esperar, con Cánones, dentro de la administración eclesiástica.

${ }^{48}$ No disponemos de los libros de cursos para Cánones de los años 1792 a 1800, de ahí que falten dos quinquenios y el siguiente comience en 1801.

49 Baeza Martín, "La condena de españoles”, pp. 1-24.

50 Si para el año 1720 se contabilizan 115 matrículas en cada facultad, en 1730 las de Cánones alcanzan las 134 mientras que las de Leyes se quedaban en 36. La coincidencia de matrículas para 1720 resulta, ciertamente, puntual e inusual. Más aproximadas a la media de estos años son las cifras, por ejemplo, del año siguiente, con 128 matrículas de Cánones frente a las 88 de Leyes. Peset, Mancebo y Peset, "La matrícula universitaria de México", pp. 99 y 105 y ss. 
La Facultad de Cánones desbancará por completo a la de Leyes para todos los parámetros: matrículas, cursos y grado con el que habilitarse de abogado. Igualmente, la inmensa mayoría de los escasos cursos ganados en Leyes, a partir de los años treinta y cuarenta, volverán a ser de primera y segunda matrícula, desapareciendo casi por completo los de tercera a quinta, tan presentes en las décadas anteriores. El grado en Leyes volvía a perder su sustantividad, recuperando su carácter complementario al de Cánones y, por lo tanto, posterior en el tiempo en su obtención.

Eso sí, si pensamos que con todo lo dicho la administración civil y las posibilidades de hacer carrera en ella quedaban definitivamente finiquitadas, la Universidad de Guadalajara nos puede desmontar esta inferencia en la medida en que, desde su misma fundación en 1791, concede a Leyes un protagonismo mucho mayor que el que tenía en la de México. Está claro que, a finales del siglo, las prioridades del municipio y del propio monarca pasarían por unos estudios con mayor presencia del Derecho real. ${ }^{51} \mathrm{Tal}$ vez se estaba pensando en ciertos cambios, lejos de una universidad, la de México, que no se atenía tan fácilmente a las voluntades del monarca. Tal vez se estaba pensando a largo plazo.

\section{A MODO DE REFLEXIÓN FINAL}

No creemos ni parece que resultara significativa la repercusión sobre la Universidad de México de la real cédula de 21 de febrero de 1776, por la que se limitaba a los criollos una tercera parte de las sillas capitulares, y cuya aplicación parece que se retrasó en el tiempo. En la línea de lo sucedido un siglo atrás, estas plazas eran verdaderamente pocas, y la demanda de canonistas para el resto de puestos de la administración eclesiástica, especialmente

51 Tormo Camallonga, "En la parte que se pueda”. 
curatos, seguía siendo la misma. ${ }^{52}$ Los embates de la monarquía borbónica a algunas corporaciones novohispanas, intensificados en las últimas décadas del siglo xviII, aunque no alcanzaban a la universidad de México, sí hicieron mella en ella, pero en el sentido contrario a las voluntades del monarca: sus intentos por introducir el Derecho real en sus aulas resultaron un completo fracaso. ${ }^{53}$ De ahí el motivo, al menos en parte, por el que se fundó la Universidad de Guadalajara en 1791, que, junto con el aumento de estudiantes en la Nueva Galicia, propiciaría la lógica mengua de los mismos en la de México.

Decimos todo esto, acontecido casi un siglo más tarde al periodo que estudiamos, porque otra posible explicación a la circunstancial profusión de Leyes en el tránsito del siglo XVII al XVIII, podríamos buscarla en razones, simplemente, universitarias, de índole interna. ${ }^{54}$ Es decir, que tendríamos que indagar en el funcionamiento de las cátedras de Cánones y de Leyes durante estos tiempos: su financiación, sus vacantes, las calidades de los catedráticos que fueron nombrados para ellas, quién sabe si posibles conflictos claustrales, etc., de tal modo que los estudiantes se viesen compelidos a matricularse y graduarse, preferentemente, en Leyes, postergando la obtención del grado en Cánones, si acaso, para mejores tiempos. ${ }^{55}$ Porque la graduación en uno u otro derecho no iba a tener repercusión alguna en la aprobación del examen de abogado, como no la iba a tener en el posterior ejercicio letrado, ni siquiera para las causas civiles. Tampoco está demostrado que en estos momentos se priorizara

52 De hecho, durante los siguientes años se mantuvo el número de cursos ganados en Cánones, aumentando incluso en la siguiente década. Si en los años setenta la media de estos cursos es de 139 por año, en los ochenta asciende a 173; AGN, Universidad, Cursos de Cánones, vols. 438 y 439. Véase también Aguirre Salvador, El mérito y la estrategia, pp. 38 y 61.

53 Hidalgo Pego, Reformismo borbónico y educación.

${ }^{54}$ AGN, Universidad, Libros de Gobierno, libro 46, fols. 46, 55, 225, 269 o 752, y libro 47, fols. 139 y ss., y 241.

55 Aguirre Salvador, Por el camino de las letras. 
a los legistas frente a los canonistas en el acceso a las plazas togadas. Es decir, nada ofrecía Leyes ante los tribunales, ni ante la administración, que no se pudiera conseguir con Cánones.

Así es que, aunque los acontecimientos que han protagonizado las referencias básicas que podían repercutir en nuestro estudio no admiten dudas en cuanto a sus fechas -tanto en su inicio como, y muy especialmente, en su final-, nos sigue sin convencer plenamente la idea de que la transitoria apetencia de los estudiantes juristas novohispanos por Leyes obedeciera a la esperanza de un mejor acceso a alguna de las poquísimas plazas togadas en los más altos tribunales de la justicia novohispana; ni siquiera, incluso, a los empleos inferiores.

Dijimos al inicio de este estudio que no íbamos a ofrecer tanto conclusiones como elementos de juicio con los que, una vez que contemos con más datos fiables, poder terminar de recomponer las piezas de este rompecabezas. Creemos que ha sido importante matizar, fundadamente, la idea de que la Universidad de México ha sido siempre canonista en sus estudios jurídicos, cosa que hasta ahora se tenía por indiscutible. En la búsqueda de explicaciones más certeras a los cambios documentados entre Leyes y Cánones, valgan estas páginas como muestra de la dificultad para entender la realidad de la administración moderna, así como las complejas relaciones de interdependencia entre sus distintas instancias, que no necesariamente tienen que significar lo que a simple vista parecen mostrar.

\section{SIGLAS Y REFERENCIAS}

AGI Archivo General de Indias, Sevilla, España.

AGN, RA Archivo General de la Nación, fondo Real Acuerdo, Ciudad de México, México.

AGN, $U$ Archivo General de la Nación, fondo Universidad, Ciudad de México, México.

ANE, FE Archivo Nacional de Ecuador, Fondo Especial, Quito, Ecuador. 
Aguirre Salvador, Rodolfo, Por el camino de las letras. El ascenso profesional de los catedráticos juristas de la Nueva España. Siglo XVIII, México, Universidad Nacional Autónoma de México, 1998.

Aguirre Salvador, Rodolfo, "La carrera de los graduados fuera de la universidad”, en MARsisKe (coord.), 2001, pp. 63-69.

Aguirre Salvador, Rodolfo, El mérito y la estrategia. Clérigos, juristas y médicos en la Nueva España, México, Universidad Nacional Autónoma de México, 2003.

Aguirre Salvador, Rodolfo, “¿Abogados o clérigos? Una disyuntiva de los juristas en la Nueva España del siglo xviII”, en PAvón Romero (coord.), 2003, pp. 85-149.

Alvarado, Lourdes (coord.), Tradición y reforma en la Universidad de México, Ciudad de México, Universidad Nacional Autónoma de México, Centro de Estudios sobre la Universidad, 2000.

Arregui Zamorano, Pilar, La Audiencia de México según los visitadores. Siglos XVI y XVII, México, Universidad Nacional Autónoma de México, 1985.

Baeza Martín, Ascensión, "La condena de españoles a obrajes en Nueva España en 1721: su secuela en la provisión de oficios de las Audiencias indianas", en Anuario de Estudios Americanos, 57: 2 (2000), pp. 449-474.

Baeza Martín, Ascensión, "Creación y reformas de un oficio inestable: el regente del Tribunal de Cuentas de México (1708-1781)", en Temas Americanistas, 27 (2011), pp. 1-24.

Batista González, Juan, La estrategia española en América durante el Siglo de las Luces, Madrid, Mapfre, 1992.

Beck Varela, Laura y Ma Julia Solla Sastre (coords.), Estudios LusoHispanos de Historia del Derecho, Madrid, Dykinson, 2018.

Burkholder, Mark A. y D. S. Chandler, Biographical Dictionary of Audiencia Ministers in the Americas, 1687-1821, Londres, Greenwood Publishing Group, 1982.

Burkholder, Mark A. y D. S. Chandler, De la impotencia a la autoridad. La Corona española y las Audiencias en América 1687-1808, México, Fondo de Cultura Económica, 1984. 
CastañEda, Carmen, "Las carreras universitarias de los graduados de la Real Universidad de Guadalajara”, en Menegus (coord.), 2001, pp. 261-280.

Castañeda, Carmen, "La Real Universidad de Guadalajara y su influencia en la sociedad tapatía”, en González González y Pérez Puente (coords.), 2005, vol. I, pp. 135-144.

Código de las Siete Partidas. Los Códigos españoles concordados y anotados, Madrid, 1872.

DíAz SÁNchez, Luis Fernando, "Las reformas borbónicas y la formación del descontento, 1765-1808”, en LARA Valdés (coord.), 2009, pp. 127-148.

Echeverría, Rogelio y Miguel Peláez Posada (coords.), Estructuras, gobierno y agentes de administración en la América española (siglos XVI, XVII y XVIII), Valladolid, Seminario Americanista de la Universidad de Valladolid, 1984.

Escamilla González, Francisco Iván, “La nueva alianza: el Consulado de México y la monarquía borbónica durante la guerra de sucesión”, en VALLE Pavón (coord.), 2003, pp. 41-66.

Escamilla GonzÁlez, Francisco Iván, Los intereses malentendidos. El Consulado de Comerciantes de México y la monarquía española, 1700-1739, México, Universidad Nacional Autónoma de México, 2011.

Escandón Bolaños, Patricia, “Apuntamientos sobre las prácticas autonómicas y democráticas del cabildo español en la América colonial de los siglos xvi y xviı", en Lizcano Fernández y Ramírez Peñaloza (coords.), 2013, pp. 93-123.

García García, Antonio, "Corrupción y venalidad en la magistratura mexicana durante el siglo XvIII”, en Illes i Imperis, 16 (2014), pp. 13-37.

García García, Antonio, "La lucha contra la corrupción judicial y gubernativa en Nueva España en las postrimerías del siglo xviıI: la visita general de Francisco Garzarón (1716-1721)", en Tiempos Modernos: Revista Electrónica de Historia Moderna, 8-35 (2017), pp. 337-362.

Gómez Gómez, Amalia, Las visitas de la Real Hacienda novobispana en el reinado de Felipe V (1710-1733), Sevilla, Escuela de Estudios HispanoAmericanos, 1979. 
GonzÁlez GonzÁlez, Enrique, "La reedición de las constituciones universitarias de México (1775) y la polémica antiilustrada”, en Alvarado (coord.), 2000, pp. 57-108.

González González, Enrique, El poder de las letras. Por una historia social de las universidades de la América hispana en el periodo colonial, México, Universidad Nacional Autónoma de México, 2017.

González González, Enrique y Leticia Pérez Puente (coords.), Permanencia y cambio. Universidades hispánicas 1551-2001, 2 vols., México, Universidad Nacional Autónoma de México, 2005.

Hidalgo Pego, Mónica, Reformismo borbónico y educación. El Colegio de San Ildefonso y sus colegiales (1768-1816), México, Universidad Nacional Autónoma de México, 2010.

Hidalgo Pego, Mónica y Rosalina Ríos Zúñiga (coords.) Poderes y educación superior en el mundo hispánico: siglos XV al XX, México, Universidad Nacional Autónoma de México, 2016.

Informe del visitador general de Nueva España, José de Gálvez, al virrey de Nueva España, Antonio Bucareli, informándole de los asuntos que ha tenido a su cargo, Archivo General de Indias, Estado, 34, N. 35.

LARA VAldÉs, José Luis (coord.), Foro de Guanajuato: nuevas interpretaciones de la Independencia de México, Guanajuato, México, Comisión Estatal para la Organización de la Conmemoración del Bicentenario, 2009.

Lizcano Fernández, Francisco y Cynthia Araceli Ramírez Peñaloza (coords.), Hacia una historia del poder en México, México, Universidad Nacional Autónoma de México, 2013.

Lohmann Villena, Guillermo, Los ministros de la Audiencia de Lima en el reinado de los Borbones (1700-1821). Esquema de un estudio sobre un núcleo dirigente, Sevilla, Escuela de Estudios Hispano-Americanos, 1974.

Marsiske, Renate (coord.), La Universidad de México. Un recorrido histórico de la época colonial al presente, México, Universidad Nacional Autónoma de México, 2001.

Martínez López, Víctor Manuel (coord.), 450 años de la Facultad de Derecho, México, Universidad Nacional Autónoma de México, 2004. 
MARTiRé, Eduardo, “Algo más sobre Derecho Indiano (entre el ius commune medieval y la modernidad)", en Anuario de Historia del Derecho Español, LXXIII (2003), pp. 231-263.

Medina, José Toribio, Historia del Tribunal del Santo Oficio de la Inquisición en México, México, Consejo Nacional para la Cultura y las Artes, 1991.

Menegus Bornemann, Margarita, "Las carreras de los graduados en Leyes y Cánones. La Nueva España en el siglo xviı", en Doctores y escolares, 2 vols., Valencia, Universitat de València, 1998, vol. II, pp. 81-91.

Menegus Bornemann, Margarita, "Tradición y reforma en la Facultad de Leyes”, en Alvarado (coord.), 2000, pp. 109-128.

Menegus, Margarita (coord.), Universidad y sociedad en Hispanoamérica. Grupos de poder siglos XVIII y XIX, México, Universidad Nacional Autónoma de México, 2001.

Muro Romero, Fernando, "Instituciones de gobierno y sociedad en Indias (1700-1760)”, en Echeverría y Peláez Posada (coords.) 1984, pp. 163-231.

Navarro García, Luis, "La participación de México en la Guerra de Sucesión española", en La Guerra de Sucesión en España y América. Actas X Jornadas Nacionales de Historia Militar, Sevilla, Deimos, 2001, pp. 279-292.

Novísima Recopilación de las Leyes de España. Mandada formar por el Señor Don Carlos IV, Madrid, 1805.

Pavón Romero, Armando (coord.), Universitarios en la Nueva España, México, Universidad Nacional Autónoma de México, 2003.

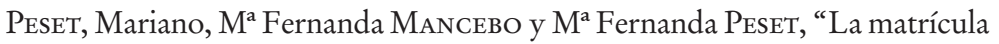
universitaria de México durante el siglo xviII", en Cuadernos del Instituto Antonio de Nebrija de Estudios sobre la Universidad, 2 (1999), pp. 83-110.

Recopilación de las leyes destos reynos hecha por mandato de la magestad cathólica del Rey don Philippe segundo nuestro señor, Alcalá de Henares, 1569.

Recopilación de Leyes de los Reynos de las Indias. Hecha por orden del Realy Supremo Consejo de las Indias, Madrid, 1791.

Rodríguez, Luis Enrique, Juan Luis Polo y Francisco Javier Alejo, “Matrículas y grados, siglos XVI-XviII", en Historia de la Universidad de Salamanca, 
4 vols., II. Estructura y Flujos, Salamanca, Universidad de Salamanca, 2004, pp. 607-663.

SÁnchez Bella, Ismael, "Edición y estudio preliminar", en Recopilación de Indias, por Antonio de León Pinelo, México, 1992.

SÁNCHEZ SANTIRó, Ernest, "Las reformas borbónicas como categoría de análisis en la historiografía institucional, económica y fiscal sobre Nueva España: orígenes, implantación y expansión”, en Historia Caribe, xI: 29 (jul.-dic. 2016), pp. 19-51.

Sanz Tapia, Ángel, "Provisión y beneficio de cargos políticos en Hispanoamérica (1682-1698)", en Estudios de Historia Social y Económica de América, 15 (1997), pp. 107-121.

SAnz TaPia, Ángel, "Aproximación al beneficio de cargos políticos americanos en la primera mitad del siglo XviII", en Revista Complutense de Historia de América, 24 (1998), pp. 147-176.

Sanz Tapia, Ángel, "Provisión, beneficio y venta de oficios americanos de Hacienda (1632-1700)", en Revista Complutense de Historia de América, 37 (2011), pp. 145-172.

SAnz TAPIA, Ángel, "La justicia en venta. El beneficio de cargos americanos de audiencia bajo Carlos II (1683-1700)", en Anuario de Estudios Americanos, 69: 1 (2012), pp. 63-90.

Tanck de Estrada, Dorothy, "Tensión en la Torre de Marfil. La educación en la segunda mitad del siglo xviII mexicano", en Josefina Zoraida VÁzQuEZ (comp.), Ensayos sobre historia de la educación en México, México, El Colegio de México, 2006, pp. 27-99.

Toribio Medina, José, Historia del Tribunal del Santo Oficio de la Inquisición en México, México, Consejo Nacional para la Cultura y las Artes, 1991.

Tormo Camallonga, Carlos, El Colegio de Abogados de Valencia. Entre el Antiguo Régimen y el liberalismo, Valencia, Universitat de València, 2004.

Tormo Camallonga, Carlos, "La abogacía en transición: continuidad y cambios del virreinato al México independiente", en Estudios de Historia Novohispana, 45 (2011), pp. 81-122. 
Tormo Camallonga, Carlos, "No sólo burocracia; cursos y matrículas en la universidad colonial de México", en Matrícula y lecciones, 2 vols., Valencia, Universitat de València, 2012, vol. II, pp. 449-473.

Tormo Camallonga, Carlos, "La renovación de la Jurisprudencia en el tránsito a la Independencia: el caso mexicano", en 1810, la Insurgencia en América, Valencia, Universitat de València, 2013, pp. 317-336.

Tormo Camallonga, Carlos, "En la parte que se pueda; norma y práctica en los grados de bachiller en Derecho en la Universidad de México", en Hidalgo Pego y Ríos ZúÑiga (coords), 2016, pp. 101-138.

Tormo Camallonga, Carlos, "La formación del jurista en el virreinato del Perú en las postrimerías del antiguo régimen", en Beck Varela y Solla SasTRE (coords.), 2018, pp. 199-237.

Tormo Camallonga, Carlos, "El régimen municipal en la Corona de Aragón en tiempos del primer municipalismo novohispano", en Segundas Jornadas Internacionales en torno a la llegada de Cortés: 1519-2019, Veracruz, 25-27 de marzo de 2019, actas en prensa.

Valle Pavón, Guillermina del (coord.), Mercaderes, comercio y consulados de Nueva España en el siglo XVIII, México, Instituto Mora, 2003. 
